\title{
Gastrointestinal response of early-weaned pigs to supplementation of wheat-soyabean meal diets with fumaric acid and sodium bicarbonate
}

\author{
R. Blank ${ }^{1}$, R. Mosenthin ${ }^{1}$ and W.C. Sauer ${ }^{2}$ \\ 'Institute of Animal Nutrition, Hohenheim University \\ D-70593 Stuttgart. Germany \\ 'Department of Agricultural, Food and Nutritional Science, \\ University of Alberta \\ Edmonton, T6G 2P5, Canada
}

\begin{abstract}
Two studies were conducted using piglets fitted with a simple T-cannula at the distal ileum to determine the effect of fumaric acid supplementation and different buffering capacities on ileal digestibilities and on the level of microbial metabolites in ileal digesta. Supplementation of fumaric acid to a diet with a low buffering capacity (Experiment 1) improved the ileal digestibilities of energy, crude protein and most of the amino acids $(\mathrm{P}<0.05)$. The decrease in microbial metabolites with increasing level of fumaric acid supplementation indicates a lower microbial activity in the upper digestive tract. Supplementation of fumaric acid to a diet with a high buffering capacity (Experiment 2 ) showed a trend $(\mathrm{P}>0.05)$ towards an increase in ileal nutrient digestibilities. Digestibility values in experiment 2 were $2-10$ percentage units lower compared to the corresponding digestibility values in Experiment 1 .
\end{abstract}

KEY WORDS: fumaric acid, buffering capacity, ileal digestibility, piglets, microbial metabolites

\section{INTRODUCTION}

Acidification of diets with fumaric acid has been shown to improve the performance of early-weaned piglets (Kirchgessner and Roth, 1976; Gicsting and Easter, 1985). Possible mechanisms for the growth-promoting effects include improvement in the digestibilities of nutrients and energy and gastro-intestinal effects, including anti-microbial effects in which potentially detrimental bacteria are inhibited as a result of a reduction in the gastric $\mathrm{pH}$ (Kirchgessner und Roth, 1988). 
However, the inability to secrete sufficient hydrochloric acid to maintain a low $\mathrm{pH}$ in the stomach seems to play a major role in the mode of action of fumaric acid. Jung and Bolduan (1986) showed that a high buffering capacity of the diet has an additional detrimental effect as it raises the level of microbial activity in the upper digestive tract. The objective of the present study was to determine the effect of fumaric acid supplementation and different buffering capacities of the diet on ileal digestibility and on the content of microbial metabolites in ileal digesta.

\section{MATERIAL AND METHODS}

Twelve piglets, weaned at 14 days of age, were used in each experiment. The piglets were housed individually in metabolic crates in a temperature-controlled barn $\left(30^{\circ} \mathrm{C}\right)$. The piglets were fitted at $15-17$ days of age with a simple T-cannula in the distal ileum according to procedures described by Li ct al. (1994). Between 14 and 20 days old the piglets were fed a non-medicated milk replacer. The piglets had no access to creep feed. Water was freely available from a low-pressurc drinking nipple.

From 21 days old the piglets were fed the experimental diets according to a balanced two-period change-over design (Gill and Magee, 1976). Treatments in Experiment 1 consisted of a wheat-soyabean meal diet ( $20 \%$ crude protein) with a low buffering capacity, without (control) or supplemented with 1, 2 and $3 \%$ fu-

TABLE 1

Formulation, $\mathrm{pH}$ and buffering capacity of the experimental diets

\begin{tabular}{|c|c|c|c|c|c|c|c|c|}
\hline \multirow{4}{*}{$\begin{array}{l}\text { Ingredients, } \mathrm{g} / \mathrm{kg} \text { diet } \\
\text { Wheat }\end{array}$} & \multicolumn{8}{|c|}{ Diets } \\
\hline & \multicolumn{4}{|c|}{ Experiment 1} & \multicolumn{4}{|c|}{ Experiment 2} \\
\hline & \multicolumn{4}{|c|}{ low buffering capacity } & \multicolumn{4}{|c|}{ high buffering capacity } \\
\hline & 494 & 494 & 494 & 494 & 494 & 494 & 494 & 494 \\
\hline Soyabean meal & 293 & 293 & 293 & 293 & 293 & 293 & 293 & 293 \\
\hline Sucrose & 100 & 90 & 80 & 70 & 70 & 60 & 50 & 40 \\
\hline Canola oil & 50 & 50 & 50 & 50 & 50 & 50 & 50 & 50 \\
\hline Vit./Min.-Premix & 40 & 40 & 40 & 40 & 40 & 40 & 40 & 40 \\
\hline Biophos & 17 & 17 & 17 & 17 & 17 & 17 & 17 & 17 \\
\hline Lysine-HCl & 3 & 3 & 3 & 3 & 3 & 3 & 3 & 3 \\
\hline Chromic oxide & 3 & 3 & 3 & 3 & 3 & 3 & 3 & 3 \\
\hline Fumaric acid & 0 & 10 & 20 & 30 & 0 & 10 & 20 & 30 \\
\hline Sodium bicarbonate & 0 & 0 & 0 & 0 & 30 & 30 & 30 & 30 \\
\hline Diet $\mathrm{pH}$ & 5.2 & 4.7 & 4.3 & 4.0 & 7.4 & 6.3 & 5.3 & 4.7 \\
\hline Buffering capacity' & 23.5 & 21.0 & 9.6 & 0 & 56.7 & 40.0 & 30.7 & 23.6 \\
\hline
\end{tabular}

' amount (ml) of $0,1 \mathrm{~N}$ hydrochloric acid to lower the diet $\mathrm{pH}$ to 4.0 
maric acid respectively. In Experiment 2, the piglets received the same diets but supplcmented with $3 \%$ sodium bicarbonate to increase the buffering capacity of each diet. The formulation of the experimental diets is shown in Table 1. The diets were formulated to meet or to exceed NRC requirements (1988). The piglets were fed three times daily at a rate of $5 \%(\mathrm{wt} / \mathrm{wt})$ of body weight. Each experimental period consisted of a 6-d adaptation period followed by collection of faeces (d 7-9) and ileal digesta (d 10-13).

The samples were freeze-dried, ground and mixed prior to analysis. Analyses for dry matter were conducted according to AOAC (1990). The buffering capacity of the diets was measured according to Bolduan et al. (1988). Crude protein content was analyzed using a Leco Nitrogen-Analyzer and the energy content was determined with the aid of an Adiabatic Bomb Calorimeter. Chromic oxide levels in feed, digesta and faeces were determined according to Fenton and Fenton (1979). Amino acid analyses were performed following acid hydrolysis in $6 \mathrm{~N} \mathrm{HCl}$ for $24 \mathrm{~h}$ according to Jones and Gilligan (1983). The $\mathrm{pH}$, as well as ammonia and lactate contents were measured in fresh digesta. Ammonia was determined with the aid of a gas sensitive electrode. D- and 1-lactic acid were determined photometrically using a test kit (Boehringer Mannheim No. 1112821).

The results were subjected to analysis of variance using the GLM procedures of SAS (1988). Least square means of treatments and periods were compared using Fisher's least significant difference procedure.

\section{RESULTS AND DISCUSSION}

The apparent ileal digestibilities of dry matter, organic matter, crude protein, energy and amino acids in Experiments 1 and 2 are presented in Table 2. Supplementation of fumaric acid to a diet with a low buffering capacity had no effect $(\mathrm{P}>0.05)$ on the ileal digestibilities of dry matter and organic matter. There were increases $(\mathrm{P}<0.05)$ in the ileal digestibilities of energy, crude protein and most of the amino acids. The highest increase, compared to the control group, was found at an inclusion level of $2 \%$ fumaric acid in the diet. Supplementation of fumaric acid to a diet with a high buffering capacity showed no effect $(\mathrm{P}<0.05)$ on the ileal digestibilities of dry matter, organic matter, crude protein, gross energy and amino acids. However, there was a trend towards an increase in ileal digestibilities when the level of fumaric acid in the diet was increased. No differences $(\mathrm{P}>0.05)$ could be found in the faecal digestibilities of any parameters measured in either experiment (data not shown). The ileal digestibilities in Experiment 2 were 2-10 percentage units lower than in Experiment 1. The $\mathrm{pH}$, dry matter, d- and 1-lactic acid and ammonia contents in ileal digesta of Experiment 1 are shown in Table 3. No treatment effects $(\mathrm{P}>0.05)$ could be found for dry matter content or $\mathrm{pH}$ of digesta. The 
TABLE 2

Ileal digestibilities of dry matter, organic matter, gross energy, crude protein and amino acids

\begin{tabular}{|c|c|c|c|c|c|c|c|c|c|c|}
\hline \multirow[b]{4}{*}{ Fumaric acid, \% } & \multicolumn{10}{|c|}{ Diets } \\
\hline & \multicolumn{5}{|c|}{ Experiment 1} & \multicolumn{5}{|c|}{ Experiment 2} \\
\hline & \multicolumn{5}{|c|}{ low buffering capacity } & \multicolumn{5}{|c|}{ high buffering capacity } \\
\hline & 0 & 1 & 2 & 3 & SEM $^{1}$ & 0 & 1 & 2 & 3 & SEM \\
\hline Dry matter & 66.5 & 68.5 & 69.1 & 68.5 & 0.9 & 62.5 & 66.8 & 67.1 & 65.1 & 3.5 \\
\hline Organic matter & 70.2 & 72.1 & 72.6 & 71.7 & 0.8 & 66.5 & 70.2 & 70.6 & 67.7 & 3.1 \\
\hline Gross energy & $71.8^{\mathrm{b}}$ & $73.6^{\mathrm{ab}}$ & $74.5^{\mathrm{a}}$ & $73.5^{\mathrm{ab}}$ & 0.7 & 64.4 & 69.7 & 70.7 & 68.0 & 3.6 \\
\hline Crude protein & $73.6^{\mathrm{b}}$ & $76.4^{\mathrm{ab}}$ & $80.9^{\mathrm{a}}$ & $77.8^{\mathrm{ab}}$ & 1.3 & 71.0 & 74.5 & 76.2 & 76.6 & 3.5 \\
\hline \multicolumn{11}{|l|}{ Amino acids: } \\
\hline \multicolumn{11}{|l|}{ Essential } \\
\hline arginine & $82.7^{\mathrm{b}}$ & $83.2^{b}$ & $88.5^{\mathrm{a}}$ & $85.5^{\mathrm{ab}}$ & 1.3 & 81.8 & 81.8 & 84.8 & 83.6 & 2.6 \\
\hline histidine & $81.2^{\mathrm{c}}$ & $85.0^{\mathrm{bc}}$ & $89.1^{\mathrm{a}}$ & $87.3^{\mathrm{ab}}$ & 0.7 & 78.8 & 83.2 & 82.9 & 82.0 & 2.7 \\
\hline isoleucine & $78.7^{\mathrm{c}}$ & $81.7^{\mathrm{b}}$ & $85.4^{\mathrm{a}}$ & $83.8^{\mathrm{ab}}$ & 0.8 & 76.9 & 79.4 & 80.3 & 80.3 & 2.8 \\
\hline leucine & $78.9^{\mathrm{b}}$ & $81.2^{\mathrm{b}}$ & $85.7^{\mathrm{a}}$ & $84.2^{\mathrm{a}}$ & 0.9 & 76.7 & 78.7 & 80.2 & 79.8 & 2.8 \\
\hline lysine & $83.4^{b}$ & $84.3^{\text {ab }}$ & $89.0^{\mathrm{a}}$ & $86.7^{\mathrm{ab}}$ & 1.4 & 74.2 & 72.5 & 80.1 & 82.0 & 6.0 \\
\hline phenylalanine & $80.1^{\mathrm{b}}$ & $82.5^{b}$ & $86.2^{\mathrm{a}}$ & $85.4^{\mathrm{a}}$ & 0.8 & 79.0 & 80.6 & 82.0 & 81.6 & 2.5 \\
\hline threonine & $68.8^{\mathrm{b}}$ & $74.1^{\mathrm{a}}$ & $77.1^{\mathrm{a}}$ & $81.9^{\mathrm{a}}$ & 1.0 & 64.1 & 69.6 & 72.3 & 74.0 & 3.9 \\
\hline valine & $76.0^{c}$ & $79.7^{b}$ & $83.1^{\mathrm{a}}$ & $81.9^{\mathrm{ab}}$ & 1.0 & 71.5 & 75.9 & 77.5 & 75.8 & 2.8 \\
\hline \multicolumn{11}{|l|}{ Non-essential } \\
\hline alanine & $67.1^{\mathrm{c}}$ & $74.9^{b}$ & $79.9^{\mathrm{a}}$ & $77.9^{\mathrm{ab}}$ & 1.3 & 68.2 & 70.1 & 73.9 & 73.1 & 3.9 \\
\hline aspartic acid & $74.6^{\mathrm{c}}$ & $77.3^{\mathrm{bc}}$ & $82.2^{\mathrm{a}}$ & $79.4^{\mathrm{ab}}$ & 1.1 & 69.1 & 74.4 & 74.6 & 73.4 & 4.0 \\
\hline glutamic acid & $86.2^{\mathrm{b}}$ & $87.6^{b}$ & $91.1^{\mathrm{a}}$ & $88.7^{\text {ab }}$ & 0.8 & 79.1 & 84.4 & 85.2 & 83.7 & 3.3 \\
\hline glycine & 65.6 & 69.4 & 74.2 & 71.2 & 2.8 & 58.2 & 64.6 & 70.2 & 66.9 & 5.8 \\
\hline serine & $75.2^{\mathrm{c}}$ & $77.9^{\mathrm{bc}}$ & $82.6^{\mathrm{a}}$ & $80.9^{\mathrm{ab}}$ & 1.0 & 74.3 & 76.7 & 79.0 & 77.7 & 3.1 \\
\hline tyrosine & $83.4^{\mathrm{ab}}$ & $81.2^{\mathrm{b}}$ & $85.6^{\mathrm{a}}$ & $83.3^{\text {ab }}$ & 1.0 & 77.7 & 77.7 & 82.7 & 83.1 & 2.8 \\
\hline
\end{tabular}

' SEM: standard error of the mean $(n=6)$

$\mathrm{a}, \mathrm{b}, \mathrm{c}-$ means in the same row with different superscripts within each experiment differ $(\mathrm{P}<0.05)$

TABLE 3

The $\mathrm{pH}$, dry matter, and contents ( $\mathrm{mmol} / 100 \mathrm{~g} \mathrm{DM}$ ) of ammonia, $\mathrm{d}$ - and l-lactic acid in ileal digesta

Experiment 1

low buffering capacity

\begin{tabular}{lccccc}
\hline Fumaric acid, $\%$ & 0 & 1 & 2 & 3 & SEM $^{1}$ \\
\hline pH & 7.1 & 7.2 & 7.2 & 7.1 & 0.1 \\
Dry matter & 7.6 & 8.3 & 8.5 & 8.2 & 0.3 \\
Ammonia & $13.8^{\mathrm{b}}$ & $13.1^{\mathrm{b}}$ & $9.5^{\mathrm{a}}$ & $11.2^{\mathrm{a}}$ & 0.7 \\
Lactic acid: & & & & & \\
$\quad$ d-lactic acid & $15.4^{\mathrm{a}}$ & $3.8^{\mathrm{b}}$ & $0.9^{\mathrm{b}}$ & $3.4^{\mathrm{b}}$ & 3.1 \\
$\quad$ 1-lactic acid & $30.8^{\mathrm{a}}$ & $14.8^{\mathrm{b}}$ & $4.7^{\mathrm{b}}$ & $11.7^{\mathrm{b}}$ & 3.5 \\
\hline
\end{tabular}

${ }^{1}$ SEM: standard error of the mean $(\mathrm{n}=6)$

$\mathrm{a}, \mathrm{b}-$ means in the same row with different superscripts differ $(\mathrm{P}<0.05)$ 
contents of $\mathrm{d}$ - and 1-lactic acid and ammonia in ileal digesta decreased $(\mathrm{P}<0.05)$ with increasing levels of fumaric acid supplementation to the diets.

These data support earlier results by Kirchgessner and Roth (1991) who reported that acidification of diets for weanling piglets improves protein and energy digestibilities due to a reduction in the gastric $\mathrm{pH}$ and a lower microbial activity in the upper part of the digestive tract.

\section{REFERENCES}

AOAC, 1990. Official Methods of Analysis. 15th Edition. Association of Official Analytical Chemists, Arlington, VA

Bolduan G., Jung H., Schneider R., Block J., Klenke B., 1988. Die Wirkung von Fumarsäure und Propandiol-Formiat in der Ferkelaufzucht. J. Anim. Physiol. Anim. Nutr. 59, 143-149

Fenton T.W., Fenton M., 1979. An improved procedure for determination of chromic oxide in feed and feces. Can. J. Anim. Sci. 59, 631-634

Giesting D.W., Easter R.A., 1985. Response of starter pigs to supplementation of com-soybean meal diets with organic acids. J. Anim. Sci. 60, 1288-1294

Gill J.L., Magee W.T., 1976. Balanced two-period change-over design for several treatments. J. Anim. Sci. 42, 775-777

Jones B.N., Gilligan J.P., 1983. O-phtaldialdehyde precolumn derivatization and reverse-phase highperformance liquid chromatography of polypeptide hydrolysates and physiological fluids. J. Chromatogr. 266, 471-482

Jung H., Bolduan G., 1986. Zur Wirkung unterschiedlicher Mineralstoffanteile in der Ration des Absetzferkels. Mh. Vet.-Med. 41, 50-52

Kirchgessner M., Roth F.X.,1976. Zum Einsatz von Fumarsäure in der Ferkelaufzucht. Züchtungskunde $48,402-406$

Kirchgessner M., Roth F.X., 1988. Ergotrope Effekte durch organische Säuren in der Ferkelaufzucht und Schweinemast. Übers. Tierernähr. 16,93-108

Kirchgessner M., Roth F.X.,1991. Ergotrope Effekte durch nutritiven Einsatz von organischen Säuren. Zbl. Hyg. 191, 265-276

Li S., Sauer W.C., Hardin R.T., 1994. Effect of dietary fibre level on amino acid digestibility in young pigs. Can. J. Anim. Sci. 74, 327-333

National Research Council, 1988. Nutrient Requirements of Swine. 9th revised Edition. National Academy Press, Washington, DC

SAS Institute, Inc., 1988. SAS/STAT user's Guide (Release 6.03). SAS Inst. Inc., Cary, NC 